Evaluation of eleven Mexican cultivars of prickly pear cactus trees for possibly utilization as animal fed: in vitro gas production

\title{
Paulina Vazquez-Mendoza, Luis
}

\section{A. Miranda-Romero, Gilberto Aranda- Osorio, Juan A. Burgueño-Ferreira \& Abdelfattah Z. M. Salem}

\section{Agroforestry Systems}

An International Journal incorporating Agroforestry Forum

ISSN 0167-4366

Volume 91

Number 4

Agroforest Syst (2017) 91:749-756

DOI 10.1007/s10457-016-9947-6

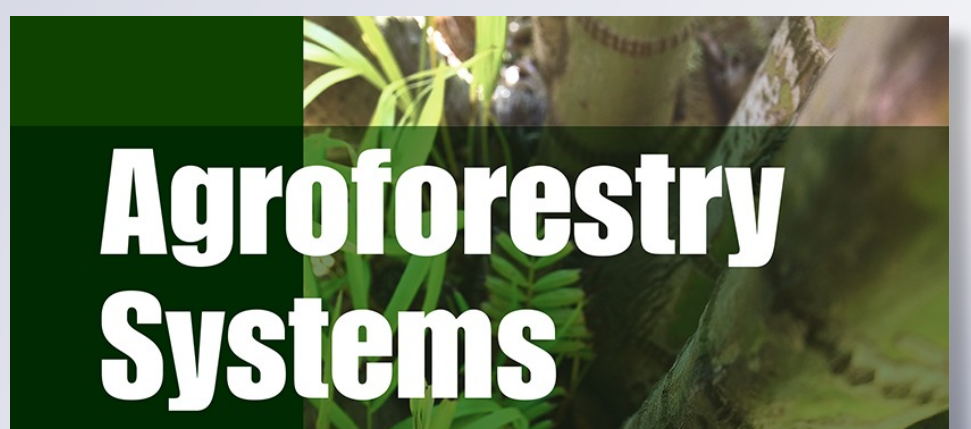

An international journal in cooperation with ICRAF

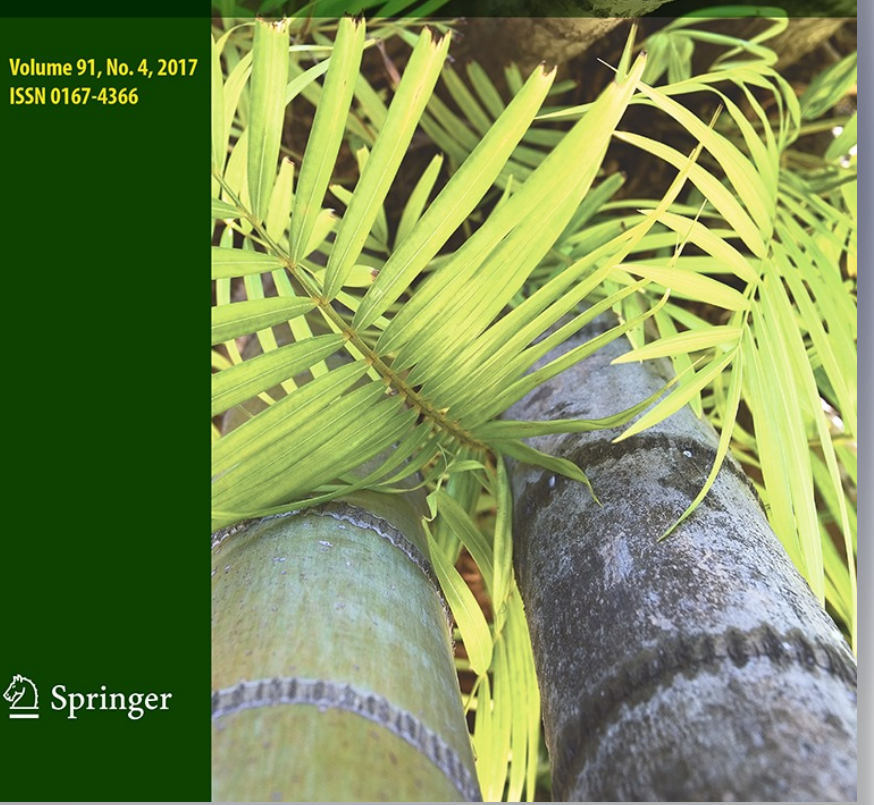


Your article is protected by copyright and all rights are held exclusively by Springer Science +Business Media Dordrecht. This e-offprint is for personal use only and shall not be selfarchived in electronic repositories. If you wish to self-archive your article, please use the accepted manuscript version for posting on your own website. You may further deposit the accepted manuscript version in any repository, provided it is only made publicly available 12 months after official publication or later and provided acknowledgement is given to the original source of publication and a link is inserted to the published article on Springer's website. The link must be accompanied by the following text: "The final publication is available at link.springer.com". 


\title{
Evaluation of eleven Mexican cultivars of prickly pear cactus trees for possibly utilization as animal fed: in vitro gas production
}

\author{
Paulina Vazquez-Mendoza • Luis A. Miranda-Romero • \\ Gilberto Aranda-Osorio · Juan A. Burgueño-Ferreira • \\ Abdelfattah Z. M. Salem
}

Received: 29 June 2015/Accepted: 19 April 2016/Published online: 25 April 2016

(C) Springer Science+Business Media Dordrecht 2016

\begin{abstract}
In production systems of prickly pear fruit and prickly pear cactus, significant amounts of pruned material, which could be used as an ingredient in animal feeding, is generated. The aim of this study was to measure the nutrient content, fermentation kinetics and in vitro digestibility of eleven cultivars of cladodes of prickly pear cactus. The fermentation was measured indirectly using the gas production technique, where $500 \mathrm{mg}$ of DM substrate (prickly pear cactus cultivars) were placed in amber glass flasks of $125 \mathrm{~mL}$ with $90 \mathrm{~mL}$ of ruminal inoculum under a continuous flow of $\mathrm{CO}_{2}$. Flasks were hermetically wrapped up with a rubber stopper and a metal ring, and were placed in a water bath at $39{ }^{\circ} \mathrm{C}$. The fermentation gas pressure was measured using a monometer at $0,2,4,6,8,12,16,20,24,32,38$, 50 and $72 \mathrm{~h}$ incubation. Results show that the chemical composition ranged between $\left(\mathrm{g} \mathrm{kg}^{-1} \mathrm{DM}\right)$ : 64 and
\end{abstract}

P. Vazquez-Mendoza · L. A. Miranda-Romero ·

G. Aranda-Osorio

Posgrado en Producción Animal, Universidad Autónoma Chapingo, Km. 38.5 Carretera México-Texcoco,

56230 Chapingo, Mexico

J. A. Burgueño-Ferreira

Centro Internacional de Mejoramiento de Maíz y Trigo, El

Batan, 56130 Texcoco, Estado de México, Mexico

\section{A. Z. M. Salem ( $\square)$}

Facultad de Medicina Veterinaria y Zootecnia, Universidad Autónoma del Estado de México, Toluca,

Estado de México, Mexico

e-mail: asalem70@yahoo.com
$160 \mathrm{~g} \mathrm{~kg}^{-1}$ dry matter (DM), $137-293 \mathrm{~g} \mathrm{~kg}^{-1} \mathrm{DM}$ ash, 52-101 $\mathrm{g} \mathrm{kg}^{-1} \mathrm{DM}$ crude protein, 3-22 $\mathrm{g} \mathrm{kg}^{-1}$ DM ether extract, 251-393 neutral detergent fiber and 132-192 acid detergent fiber. The gas volume was different $(\mathrm{p}<0.05)$ among cultivars, with the Red Vigor cultivar having the largest volume at $378 \mathrm{~mL} \mathrm{~g}^{-1}$ DM. The highest volume of gas was produced during the first $24 \mathrm{~h}$ in on average $67 \%$ of the total produced. The in vitro DM digestibility displayed values of up to $82 \%$ in the Roja Pelota cultivar. It can be concluded that the cladodes of prickly pear cactus from different cultivars can be used in animal feed for its good rumen fermentation characteristics.

Keywords Fermentation - Gas production Chemical composition · Prickly pear

\section{Introduction}

The prickly pear cactus (Opuntia spp.) is an endemic cactus of Americas with 258 identified species, a hundred of which are located in Mexico (Rodriguez et al. 2009). This plant grows in water-scarce regions, high temperatures and poor soils (Fuentes-Rodríguez 1997; Luttge 2004; De Waal et al. 2006). In arid areas of northern Mexico, the prickly pear cactus is used for animal feed as a source of fodder, energy and water (Andrade-Montemayor et al. 2011); while in the central region of Mexico it is used in the intensive production of 
prickly pear fruit and tender prickly pear cactus for human consumption. In addition, a lesser amount of slightly lignified prickly pear cactus is used as animal fodder (Felker et al. 2006). The prickly pear cactus farming production in Mexico City, the states of Mexico and Puebla represents $37 \%$ of the total Mexican production (SIAP 2010). In these farming systems, trimming of cladodes is a common practice where large quantities of waste are generated, if which are handled correctly can be a source of organic matter, however, without proper management can represents a source of contamination, pests and diseases (CONAZA 1994). Nevertheless, because of its digestible nutrients content, trimming waste of prickly pear cactus can be used in the intensive feeding of ruminants. It has been shown that it is possible to include 17 to $25 \%$ of dried and milled prickly pear cactus forage, totally mixed rations to fatten ovine and achieve a similar growth performance to those viewed with commercial diets, therefore the use of prickly pear cactus is a viable strategy for the producer (Aguilar-Yáñez et al. 2011; Muciño-Castillo et al. 2014). However, the animal response depends more on the nutritional quality of the ingredients in the diet, and the prickly pear cactus nutrient content can vary (Granados and Castañeda 1996).

To date there are no studies of the nutrient content of trimmed cladodes waste and its fermentation by microbial inoculum from the rumen of ovine. Therefore the aim of this study was to measure the nutrient content, fermentation kinetics and in vitro digestibility of cladodes waste from eleven prickly pear cactus cultivars grown in San Sebastian Villanueva, Acatzingo, Puebla, Mexico.

\section{Materials and methods}

Vegetal material

During March 2013, eleven cultivars of prickly pear cactus were studied, ten samples of trimmed material between 1 to 3 years to cultivate were randomly taken from producers' plots from the San Sebastian Villanueva, Acatzingo, Puebla, located $19^{\circ} 03^{\prime} 37^{\prime \prime}$ North Latitude, $97^{\circ} 42^{\prime} 58^{\prime \prime}$ west longitude and $2232 \mathrm{~m}$ above sea level, with temperature and annual rainfall of $17.9{ }^{\circ} \mathrm{C}$ and $674 \mathrm{~mm}$, and cambisol being the dominant soil type (García 1988).

The used cultivars of prickly pear fruit were: (Opuntia ficus-indica cv. Rojo vigor), (Opuntia joconostle), (Opuntia ficus-indica cv. Villanueva), (Opuntia ficus-indica cv. Sangre de Cristo), (Opuntia ficus-indica cv. Burrona), (Opuntia ficus-indica cv. Cristalina), (Opuntia ficus-indica cv. Roja San Martin), (Opuntia ficus-indica cv. Ceniza Roja), (Opuntia ficus-indica $c v$. Roja Pelota) and cultivars for prickly pear cactus were (Opuntia ficus-indica cv. Atlixco) and (Opuntia ficus-indica cv. Milpa Alta).

Chemical analysis

Fresh cladodes of each prickly pear cactus cultivar were cut into thin slices, dried at $65{ }^{\circ} \mathrm{C}$ in a forced air oven until a constant weight was obtained and milled to $1 \mathrm{~mm}$ (Thomas Wiley ${ }^{\circledR}$ Mini-Mill, Texcoco, México). A composite sample of each prickly pear cactus was used to measure the content of crude protein $(\mathrm{CP})$, ash (A), ether extract (EE) (AOAC 1990); neutral detergent fiber (NDF) and acid detergent fiber (ADF) (Van Soest et al. 1991). Atomic absorption method was used to detect the contents of $\mathrm{Ca}, \mathrm{Mg}, \mathrm{Na}, \mathrm{K}, \mathrm{Cu}, \mathrm{Fe}, \mathrm{Zn}$ and Mn (A Analyst 700, Perkin-Elmer, Texcoco, México. 1996; AOAC 1990), and $\mathrm{P}$ by colorimetry (UV/VIS Lambda 2 spectrometer model Perkin Elmer, Texcoco, México; AOAC 1990). The contents of total carbohydrates (TC: Sniffen et al. 1992), Non-fibrous carbohydrates (NFC: NRC 2001) and hemicelluloses (HC) were calculated.

Fermentation and in vitro digestibility

The fermentation was measured indirectly using the gas production technique (Menke and Steingass 1988; Theodorou et al. 1994), where 500 mg of DM substrate (prickly pear cactus cultivars) were placed in $125 \mathrm{~mL}$ amber glass flasks with $90 \mathrm{~mL}$ of ruminal inoculum under a continuous flow of $\mathrm{CO}_{2}$. Flasks were hermetically wrapped up with a rubber stopper and a metal ring, and were placed in a water bath at $39{ }^{\circ} \mathrm{C}$. The fermentation gas pressure was measured with a monometer (0-1 kg cm ${ }^{2}$; METRON ${ }^{\circledR} 51100$, Texcoco, México) at 0, 2, 4, 6, 8, 12, 16, 20, 24, 32, 38, 50 and $72 \mathrm{~h}$ incubation. Measured pressures were converted into volume with the $\mathrm{V}$ regression model $(\mathrm{mL})=[\mathrm{P}$ $\left.\left(\mathrm{kg} \mathrm{cm}^{2}\right)+0.0495\right] / 0.0185$, this model was obtained by measuring the pressure generated by known volumes of gas injected into the flasks under the same handling conditions. The fractional gas volume was calculated $\left(\mathrm{mL} \mathrm{g}{ }^{-1} \mathrm{DM}\right)$ for time intervals of 0 to $8\left(\mathrm{Fv}_{0-8}\right), 8$ to 24 
$\left(\mathrm{Fv}_{8-24}\right)$ and 24 to $50\left(\mathrm{Fv}_{24-50}\right)$ hours of incubation. The accumulated volume for each measured time was also measured and used to estimate the maximum volume $\left(\mathrm{Mv} ; \mathrm{mL} \mathrm{g}^{-1} \mathrm{DM}\right)$, the gas production rate $\left(\mathrm{S} ; \mathrm{mL} \mathrm{h}^{-1}\right)$ and the phase lag $(\mathrm{L} ; \mathrm{h})$ of gas production, which were adjusted with the logistic model $\mathrm{Vo}=\mathrm{Mv} /$ $\left(1+\mathrm{e}^{\left(2-4 * \mathrm{~S}^{*}(\mathrm{TL})\right.}\right)$ (Pitt et al. 1999). The in vitro dry matter digestibility (IVDMD) was calculated by the difference between the weight of the starting matter before and after incubation for $72 \mathrm{~h}$ of incubation, and the potential emission rate of fermentation gases (PERFG), was calculated by dividing the maximum volume of gas production from every cultivar divided by its in vitro dry matter digestibility value.

The rumen inoculum was obtained from three ovine with rumen cannula fed with silage and corn stubble (70:30 DM). At the moment of sampling of ruminal fluid, the ovine were fasted for $12 \mathrm{~h}$. Rumen contents were filtered through four layers of gauze and mixed with a mineral solution reduced to a $1: 9(\mathrm{v} / \mathrm{v})$. The mineral solution contained: $\mathrm{K}_{2} \mathrm{HPO}_{4}\left(0.45 \mathrm{~g} \mathrm{~L}^{-1}\right)$, $\mathrm{KH}_{2} \mathrm{PO}_{4}\left(0.45 \mathrm{~g} \mathrm{~L}^{-1}\right),\left(\mathrm{NH}_{4}\right)_{2} \mathrm{SO}_{4}\left(0.45 \mathrm{~g} \mathrm{~L}^{-1}\right), \mathrm{NaCl}$ $\left(0.90 \mathrm{~g} \mathrm{~L}^{-1}\right), \mathrm{MgSO}_{4}\left(0.18 \mathrm{~g} \mathrm{~L}^{-1}\right), \mathrm{CaCl}_{2}(0.12 \mathrm{~g}$ $\left.\mathrm{L}^{-1}\right), \mathrm{Na}_{2} \mathrm{CO}_{3}\left(4 \mathrm{~g} \mathrm{~L}^{-1}\right)$, the reducing solution contained: $\mathrm{NaOH}\left(0.8 \mathrm{ml} \mathrm{L}^{-1}\right), \mathrm{Na}_{2} \mathrm{~S}\left(0.2 \mathrm{~g} \mathrm{~L}^{-1}\right)$, L-cysteine $\left(0.2 \mathrm{~g} \mathrm{~L}^{-1}\right)$ and 1 drop of rezarzurina (Cobos and Yokoyama 1995).
Statistical analysis

It was used a completely randomized design, using the SAS GLM procedure, and the means comparison test was done with LSMEANS, used only for Mv, S, L, $\mathrm{Fv}_{0-8}, \mathrm{Fv}_{8-24}, \mathrm{Fv}_{24-50}, I V D M D_{72}$ and PERFG variables, when there were differences test Tukey was used.

\section{Results}

The nutrient contents of the eleven trimmed cladodes of prickly pear cactus cultivars are shown in Table 1 . In general, the cladodes had a low content of DM and a high content of ashes. The prickly pear cactus cladodes are characterized for containing a low amount of CP, the CP in the Roja San Martin, Atlixco and Cristalina cultivars, varied between 90 and $100 \mathrm{~g} \mathrm{~kg}^{-1} \mathrm{DM}$, the other cultivars had a lower content than between 90 and $60 \mathrm{~g} \mathrm{~kg}^{-1} \mathrm{DM}$. The EE was lower than $18 \mathrm{~g} \mathrm{~kg}^{-1} \mathrm{DM}$ and NDF was low with a range between 251 to $383 \mathrm{~g} \mathrm{~kg}^{-1} \mathrm{DM}$; consequently, the ADF was low $\left(<193 \mathrm{~g} \mathrm{~kg}^{-1} \mathrm{DM}\right)$ for all the cultivars. Due to the low ADF, the hemicellulose represents a high proportion of NDF which varied between 36 to $65 \%$. The cultivars with the highest proportion of hemicellulose in the NDF were Rojo

Table 1 Chemical composition $\left(\mathrm{g} \mathrm{kg}^{-1} \mathrm{DM}\right)$ of cladodes pruning of cactus cultivars

\begin{tabular}{|c|c|c|c|c|c|c|c|c|c|}
\hline \multirow[t]{2}{*}{ Cultivars } & \multicolumn{9}{|l|}{ Component } \\
\hline & $\begin{array}{l}\mathrm{DM} \\
\mathrm{g} \mathrm{kg}^{-1} \mathrm{WM}\end{array}$ & $\begin{array}{l}\text { Ash } \\
\mathrm{g} \mathrm{kg}^{-1} \mathrm{MS}\end{array}$ & $\mathrm{CP}$ & $\mathrm{EE}$ & NDF & $\mathrm{ADF}$ & $\mathrm{TC}$ & NFC & $\mathrm{HC}$ \\
\hline Roja Vigor & 160.00 & 137.03 & 86.29 & 12.80 & 379.50 & 161.83 & 763.88 & 384.38 & 217.67 \\
\hline Xoconostle & 111.11 & 224.31 & 75.61 & 22.15 & 393.24 & 192.15 & 677.93 & 284.69 & 201.09 \\
\hline Villanueva & 86.96 & 237.47 & 68.08 & 18.90 & 312.90 & 152.99 & 675.55 & 362.65 & 159.91 \\
\hline Sangre de Cristo & 113.64 & 215.9 & 58.18 & 8.20 & 290.08 & 174.63 & 717.72 & 427.64 & 115.45 \\
\hline Milpa Alta & 90.91 & 229.19 & 67.21 & 5.70 & 299.43 & 188.97 & 697.90 & 398.47 & 110.46 \\
\hline Burrona & 113.64 & 278.18 & 52.48 & 3.00 & 383.27 & 133.40 & 666.34 & 283.07 & 249.87 \\
\hline Atlixco & 69.44 & 286.8 & 96.16 & 10.95 & 288.87 & 178.15 & 606.09 & 317.22 & 110.72 \\
\hline Cristalina & 64.81 & 293.61 & 89.01 & 18.60 & 251.88 & 155.87 & 598.78 & 346.90 & 96.01 \\
\hline Roja San Martin & 75.76 & 268.05 & 101.77 & 11.20 & 277.36 & 134.72 & 618.98 & 341.62 & 142.64 \\
\hline Ceniza Roja & 125.00 & 241.21 & 66.06 & 8.50 & 264.62 & 132.38 & 684.23 & 419.61 & 132.24 \\
\hline Roja Pelota & 125.00 & 251.92 & 70.98 & 8.60 & 285.17 & 153.82 & 668.50 & 383.33 & 131.35 \\
\hline $\mathrm{CV}$ & 27.78 & 17.97 & 20.82 & 50.92 & 16.11 & 13.46 & 7.29 & 13.83 & 33.09 \\
\hline SD & 28.70 & 43.54 & 15.74 & 5.95 & 50.19 & 21.53 & 48.93 & 49.67 & 50.17 \\
\hline
\end{tabular}

$D M$ dry matter, $C P$ crude protein, $E E$ ether extract, $N D F$ neutral detergent fiber, $A D F$ acid detergent fiber, $C T$ total carbohydrates, $N F C$ non-fibrous structural carbohydrates, $H C$ hemicellulose, $C V$ coefficient of variation, $S D$ standard deviation, $W M$ wet matter 
Table 2 Mineral concentrations $\left(\mathrm{g} \mathrm{kg}^{-1}\right.$ DM) of cladodes of prickly pear cultivars pruning

$C V$ coefficient of variation, $S D$ standard deviation

\begin{tabular}{|c|c|c|c|c|c|c|c|c|c|}
\hline Cultivars & $\begin{array}{l}\mathrm{P} \\
\mathrm{g} \mathrm{kg}^{-1}\end{array}$ & $\begin{array}{c}\mathrm{Ca} \\
\mathrm{DM}\end{array}$ & $\mathrm{Mg}$ & $\mathrm{K}$ & $\mathrm{Na}$ & $\begin{array}{l}\mathrm{Cu} \\
\mathrm{mg} \mathrm{kg}\end{array}$ & $\begin{array}{l}\mathrm{Fe} \\
{ }^{1} \mathrm{DM}\end{array}$ & $\mathrm{Zn}$ & $\mathrm{Mn}$ \\
\hline Roja Vigor & 1.61 & 19.53 & 16.18 & 29.57 & 0.25 & 2.38 & 91.88 & 54.01 & 220.18 \\
\hline Xoconostle & 1.06 & 24.18 & 14.63 & 34.61 & 0.27 & 4.78 & 46.27 & 109.56 & 144.30 \\
\hline Villanueva & 2.48 & 26.31 & 10.54 & 45.18 & 0.46 & 2.32 & 60.15 & 59.19 & 128.38 \\
\hline Sangre de Cristo & 0.99 & 33.56 & 14.60 & 28.32 & 0.16 & 7.11 & 30.59 & 65.04 & 131.08 \\
\hline Milpa Alta & 1.14 & 27.23 & 16.90 & 23.29 & 0.16 & 14.20 & 28.65 & 75.68 & 65.31 \\
\hline Burrona & 1.89 & 32.29 & 18.36 & 18.43 & 0.41 & 9.31 & 75.34 & 95.06 & 80.57 \\
\hline Atlixco & 1.01 & 30.74 & 17.64 & 32.36 & 0.22 & 4.49 & 58.43 & 71.88 & 196.40 \\
\hline Cristalina & 2.76 & 35.43 & 9.95 & 43.58 & 0.25 & 2.33 & 60.34 & 358.14 & 232.60 \\
\hline Roja San Martin & 1.16 & 31.94 & 15.18 & 37.20 & 0.24 & 2.46 & 63.18 & 20.45 & 124.09 \\
\hline Ceniza Roja & 1.24 & 40.10 & 13.24 & 29.47 & 0.27 & 3.59 & 77.11 & 329.15 & 227.14 \\
\hline Roja Pelota & 1.27 & 13.13 & 8.23 & 18.20 & 0.23 & 4.79 & 46.36 & 52.49 & 145.42 \\
\hline $\mathrm{CV}$ & 40.66 & 26.66 & 23.43 & 30.19 & 34.82 & 70.47 & 33.31 & 97.52 & 37.38 \\
\hline SD & 0.61 & 7.62 & 3.31 & 9.41 & 0.09 & 3.70 & 19.33 & 114.42 & 57.63 \\
\hline
\end{tabular}

Vigor $(57 \%)$ and Burrona (65 \%). The total carbohydrates in the cultivars presenting values between 598 and $763 \mathrm{~g} \mathrm{~kg}^{-1} \mathrm{DM}$, the content of non-fibrous carbohydrates cultivars ranged between 283 and $427 \mathrm{~g} \mathrm{~kg}^{-1} \mathrm{DM}$ and represent a $46 \%$ average from the total carbohydrates.

The variability in the mineral content of cladodes was also wide (Table 2). Among the macrominerals, $\mathrm{Ca}, \mathrm{K}$ and $\mathrm{Mg}$ were those found in greater concentrations; with contents ranging from 11 to 41,18 to 45 and
18 to $8 \mathrm{~g} \mathrm{~kg}^{-1}$ DM respectively; the ones with the least amount were $\mathrm{P}$ and $\mathrm{Na}$ with values from 0.9 to 2 and 0.1 to $0.4 \mathrm{~g} \mathrm{~kg}^{-1} \mathrm{DM}$. The microminerals with the most cladodes were the $\mathrm{Mg}$ with values from 65 to $227, \mathrm{Zn}$ from 20 to 358 and $\mathrm{Fe}$ from 28 to $91 \mathrm{mg} \mathrm{kg}^{-1} \mathrm{DM}, \mathrm{Cu}$ presented low amounts with 2 and $9 \mathrm{mg} \mathrm{kg}^{-1} \mathrm{DM}$.

The values of the variables for the fermentation kinetics of gas production ( $\mathrm{Mv}, \mathrm{Fv}_{0-8}, \mathrm{Fv}_{8-24}, \mathrm{Fv}_{24-50}$, $\mathrm{S}$ and $\mathrm{L}$ ), in vitro digestibility and the potential emission rate of gas are shown in Table 3. There were

Table 3 Variables of gas production and fermentation kinetics ( $\mathrm{Mv}, \mathrm{Vf}_{0-8}, \mathrm{Vf}_{8-24}, \mathrm{Vf}_{24-50}, \mathrm{~S}$ and $\mathrm{L}$ ), in vitro digestibility and potential emission rate of fermentation gases in cladodes pruning of cultivars of prickly pear cactus

\begin{tabular}{|c|c|c|c|c|c|c|c|c|}
\hline Cultivars & $\begin{array}{l}\mathrm{Mv} \\
\mathrm{mL} \mathrm{g}^{-1}\end{array}$ & $\begin{array}{l}\mathrm{Fv}_{0-8} \\
\mathrm{M}\end{array}$ & $\mathrm{Fv}_{8-24}$ & $\mathrm{Fv}_{24-50}$ & $\mathrm{~S}\left(\mathrm{~mL} \mathrm{~h} \mathrm{~h}^{-1}\right)$ & $\mathrm{L}(\mathrm{h})$ & IVDMD (\%) & PERFG ( $\left.\mathrm{mL} \mathrm{g}^{-1} \mathrm{DMD}\right)$ \\
\hline Roja Vigor & $378.33^{\mathrm{a}}$ & $132.63^{\mathrm{ab}}$ & $167.03^{\mathrm{a}}$ & $84.91^{\mathrm{a}}$ & $0.0400^{\mathrm{abc}}$ & $2.83^{\mathrm{a}}$ & $76.19^{\mathrm{bc}}$ & $496.99^{\mathrm{a}}$ \\
\hline Xoconostle & $289.90^{\mathrm{b}}$ & $102.60^{\mathrm{ab}}$ & $129.22^{\mathrm{b}}$ & $63.93^{\mathrm{ab}}$ & $0.0406^{\mathrm{abc}}$ & $2.72^{\mathrm{a}}$ & $75.55^{\mathrm{bc}}$ & $384.08^{\mathrm{b}}$ \\
\hline Villanueva & $305.03^{\mathrm{b}}$ & $134.25^{\mathrm{a}}$ & $123.02^{\mathrm{bc}}$ & $59.10^{\mathrm{b}}$ & $0.0456^{\mathrm{a}}$ & $1.85^{\mathrm{abc}}$ & $78.46^{\mathrm{ab}}$ & $388.84^{\mathrm{b}}$ \\
\hline Sangre de Cristo & $266.33^{b}$ & $102.79^{\mathrm{ab}}$ & $99.66^{\text {bcde }}$ & $65.49^{\mathrm{ab}}$ & $0.0353^{\mathrm{bc}}$ & $0.86^{\text {bcd }}$ & $72.30^{\mathrm{cd}}$ & $369.07^{\mathrm{b}}$ \\
\hline Milpa Alta & $244.40^{\mathrm{b}}$ & $93.91^{\mathrm{b}}$ & $83.09^{\mathrm{de}}$ & $65.39^{\mathrm{ab}}$ & $0.0320^{\mathrm{c}}$ & $0.28^{\mathrm{d}}$ & $69.82^{\mathrm{d}}$ & $350.12^{b}$ \\
\hline Burrona & $254.93^{\mathrm{b}}$ & $111.53^{\mathrm{ab}}$ & $93.96^{\mathrm{cde}}$ & $55.27^{\mathrm{b}}$ & $0.0410^{\mathrm{abc}}$ & $0.94^{\text {bcd }}$ & $71.58^{\mathrm{cd}}$ & $356.32^{\mathrm{b}}$ \\
\hline Atlixco & $241.20^{\mathrm{b}}$ & $86.54^{\mathrm{b}}$ & $97.29^{\text {cde }}$ & $59.10^{\mathrm{b}}$ & $0.0356^{\mathrm{bc}}$ & $1.82^{\mathrm{abc}}$ & $69.76^{\mathrm{d}}$ & $347.34^{\mathrm{b}}$ \\
\hline Cristalina & $244.80^{\mathrm{b}}$ & $105.49^{\mathrm{ab}}$ & $90.44^{\mathrm{de}}$ & $53.60^{\mathrm{b}}$ & $0.0383^{\mathrm{abc}}$ & $0.79^{\mathrm{cd}}$ & $72.47^{\mathrm{b}}$ & $339.44^{\mathrm{b}}$ \\
\hline Roja San Martín & $235.13^{\mathrm{b}}$ & $97.12^{\mathrm{b}}$ & $98.72^{\text {bcde }}$ & $45.43^{\mathrm{b}}$ & $0.0426^{\mathrm{ab}}$ & $1.86^{\mathrm{abc}}$ & $72.94^{\text {bcd }}$ & $322.04^{\mathrm{b}}$ \\
\hline Ceniza Roja & $248.00^{\mathrm{b}}$ & $111.65^{\mathrm{ab}}$ & $80.91^{\mathrm{e}}$ & $56.22^{\mathrm{b}}$ & $0.0360^{\mathrm{bc}}$ & $0.00^{\mathrm{d}}$ & $73.69^{\text {bcd }}$ & $336.70^{\mathrm{b}}$ \\
\hline Roja Pelota & $271.77^{\mathrm{b}}$ & $101.92^{\mathrm{ab}}$ & $112.94^{\mathrm{bcd}}$ & $61.36^{\mathrm{b}}$ & $0.0400^{\mathrm{abc}}$ & $1.99^{\mathrm{ab}}$ & $82.78^{a}$ & $328.30^{\mathrm{b}}$ \\
\hline SEM & 14.29 & 6.38 & 6.15 & 4.49 & 0.0017 & 0.22 & 3.21 & 20.06 \\
\hline
\end{tabular}

$M v$ maximum volume a $72 \mathrm{~h}$ of incubation; $V f_{0-8}$, accumulate volume of 0 to $8 \mathrm{~h} ; F v_{8-24}$, accumulate volume of 8 to $24 \mathrm{~h} ; F v_{24-50}$, accumulate volume of 24 to $50 \mathrm{~h} ; S$ rate of gas production; $L$ time lag; IVDMD in vitro dry matter digestibility; $P E R F G$ potential emission rate of fermentation gases; $D M D$ dry matter digested. SEM pooled standard error of the mean; Means in the same column with different letters are different $(\mathrm{p}<0.05)$ 
differences among cultivars of $(\mathrm{p}<0.05)$. The Rojo Vigor cultivar had the maximum volume of gas production $(\mathrm{Mv})$, higher than $(\mathrm{p}<0.05$; $378 \mathrm{~mL} \mathrm{~g}^{-1}$ ), regarding the other ten cultivars, which had an $\mathrm{Mv}$ between 235 and $305 \mathrm{~mL} \mathrm{~g}^{-1}$.

Regarding the volume of gas accumulated in the first eight hours of incubation $\left(\mathrm{Fv}_{0-8}\right)$ the Milpa Alta, Atlixco and Roja San Martin cultivars produced the least volume $(\mathrm{p}<0.05)$ in comparison with the Villanueva Cultivar. The volume of gas between eight and $24 \mathrm{~h}\left(\mathrm{Fv}_{8-24}\right)$, was more diversity, the Ceniza Roja, Cristalina and Milpa Alta cultivars the ones which produced less $\mathrm{Fv}_{8-24}(\mathrm{p}<0.05)$ regarding: Xoconostle, Villanueva, and Rojo Vigor cultivars. In the volume of gas between 24 to $50 \mathrm{~h}$ of incubation, the cultivars of lower $\mathrm{Fv}_{24-50}(\mathrm{p}<0.05)$ were the Burrona, Atlixco, Cristalina, Rojo San Martin, Ceniza Roja and Roja Pelota cultivars (61 $\left.\mathrm{mL} \mathrm{g}^{-1} \mathrm{DM}\right)$, in comparison with the Rojo Vigor $\left(84 \mathrm{~mL} \mathrm{~g}^{-1} \mathrm{DM}\right)$. Regarding the gas production rate, the Villanueva cultivar had the highest rate $\left(0.0456 \mathrm{~h}^{-1} ; \mathrm{p}<0.05\right)$ of gas production $(\mathrm{S})$ in comparison with Milpa Alta, Sangre de Cristo, Atlixco and Ceniza Roja. The lag phase (L) was short as this was the same to or less than $2.83 \mathrm{~h}$.

Regarding the in vitro dry matter digestibility (IVDMD) a variation between 69 and $82 \%$ was observed. The potential emission rate of fermentation gases ( $\mathrm{mL} \mathrm{g}^{-1}$ digested DM), ranged between 322 and $496 \mathrm{~mL} \mathrm{~g}^{-1} \mathrm{DM}$, the Roja Vigor cultivar, with the highest emission rate, was $29 \%$ higher than the average of the other cultivars.

\section{Discussion}

\section{Chemical composition}

The composition of the prickly pear cactus varies in relation to the factors to which it is exposed (Granados and Castañeda 1996), some of them can be the cultivar, ripeness, humidity, composition of nutrients in the soil, fertilization and agronomic practices (Dubeux et al. 2006). The evaluated cultivars showed low levels of DM and EE, similar to those reported by Batista et al. (2003, 2009) and Pinos-Rodríguez et al. (2010) and in Gigante cultivars, IPA-20 Algeria and forage, respectively. The protein showed low values similar to those reported by Tegegne et al. (2007) and Tegegne (2001), under conditions without fertilization, however, this nutrient can be affected by soil moisture and fertilization as showed by Pinos-Rodríguez et al. (2010), when evaluated the effect of irrigation and fertilization in the cladodes composition at different ages, finding a linear relationship between age and protein content, as age increases the protein content decreases. The reported values are moderate and go from 18 to $10 \%$ at 30 and 90 days respectively, compared to the protein content in alfalfa and corn.

Regarding its fiber fractions (NDF and ADF), Pinos-Rodríguez et al. (2010) found a linear relationship, as the prickly pear cactus ripens the fiber increases too. The NDF and ADF values obtained in this study for prickly pear cactus cultivars were similar to those reported by other authors (Gebremariam et al. 2006; Batista et al. 2009; Costa et al. 2009; Barbosa et al. 2012). The hemicellulose content calculated in this study varied in ranges from 96 to $249 \mathrm{~g} \mathrm{~kg}^{-1} \mathrm{DM}$, similar values to those reported in studies of Batista et al. (2003) and Abidi et al. (2009) where the estimated difference between NDF and ADF values were in average 102 and 123 respectively.

The total carbohydrate content was an average of $670 \mathrm{~g} \mathrm{~kg}^{-1} \mathrm{DM}$, lower values than those reported by Batista et al. (2003), who found an average of $751 \mathrm{~g} \mathrm{~kg}^{-1}$ DM of total carbohydrates in three prickly pear cactus cultivars. Silva et al. (2011) mentioned that the prickly pear cactus stands out because of a high content of nonfibrous carbohydrates, with a $49.7 \%$ higher value than sorghum grains. Meanwhile Batista et al. (2003) reported that the carbohydrate fraction of medium and rapid fermentation constitutes as 19 and $42 \%$ respectively of the total, due to high content of these components and low levels of lignin, the prickly pear cactus can be considered as a good source of fermentable carbohydrates for ruminants (Batista et al. 2009).

The ash content ranged between 137 to $293 \mathrm{~g} \mathrm{~kg}^{-1}$ $\mathrm{DM}$, in the studied cultivars was lower than that reported by Ben Salem et al. (2002) for the Inermis cultivar and superior to that found by RodríguezGarcía et al. (2007) for the Redonda cultivar. The amount of minerals in the prickly pear cactus can be determined by the mineral content of the soil (Nobel, 2002). The water deficiency and high levels of minerals in the soil make the prickly pear cactus accumulate high amounts of $\mathrm{Ca}$ (Nobel 2002). McConn and Nakata (2004) found $18 \mathrm{~g} \mathrm{~kg}^{-1} \mathrm{DM}$, Rodríguez-García et al. (2007) reported values between 15 to $37 \mathrm{~g} \mathrm{~kg}^{-1} \mathrm{DM}$, according to the 
ripening state of the cladode; and Batista et al. (2003) $70 \mathrm{~g} \mathrm{~kg}^{-1} \mathrm{DM}$, of $\mathrm{Ca}$. This last value was much higher than the one found in this study (13-40 $\left.\mathrm{g} \mathrm{kg}^{-1} \mathrm{DM}\right)$. The $\mathrm{Ca}$ is an essential mineral in animal nutrition; however, even though the prickly pear cactus cultivars had high content of $\mathrm{Ca}$, this does not ensure that they are a source of calcium since it is found in oxalate crystals (McConn and Nakata 2004), with low availability (Ben Salem et al. 2002). On the other hand, Rodríguez-García et al. (2007) indicated that the content of calcium oxalates decrease as cladode age progresses, this can occurred for pruned cladodes, as the ones used in this study.

The $\mathrm{P}$ with ranges from 0.9 to $2.7 \mathrm{~g} \mathrm{~kg}^{-1} \mathrm{DM}$ was lower than those reported by Batista et al. (2003) with average values of 5.6 in three varieties of prickly pear cactus, and it remains within the values reported by Tegegne (2002) of $2.3 \mathrm{~g} \mathrm{~kg}^{-1} \mathrm{DM}$ and RodríguezGarcía et al. (2007) of $1.8 \mathrm{~g} \mathrm{~kg}^{-1} \mathrm{DM}$, who found that contrary to the case of $\mathrm{Ca}$, while the cladodes age increases $\mathrm{P}$ concentration decreases.

The K content ranged between 18 and $45 \mathrm{~g} \mathrm{~kg}^{-1} \mathrm{DM}$ which is lower than those reported by McConn and Nakata (2004), in cladodes of different ages. Kafkafi and $\mathrm{Xu}$ (1999) mentioned that the K level varied in different organs of the plants, focusing in flowers and fruits and that is decreased as the cladodes age progresses on flowers and fruits and this decreases as the cladodes age advances. Tegenge (2002) reported K values of $1.7 \mathrm{~g} \mathrm{~kg}^{-1} \mathrm{DM}$ well below those found in this study.

Meanwhile, the $\mathrm{Mg}$ content ranged from 8 to $18 \mathrm{~g} \mathrm{~kg}^{-1} \mathrm{DM}$ in this study was higher in some cultivars to those reported by McConn and Nakata (2004) of $10 \mathrm{~g} \mathrm{~kg}^{-1} \mathrm{DM}$ and Rodríguez-García et al. (2007) of $6 \mathrm{~g} \mathrm{~kg}^{-1} \mathrm{DM}$, meanwhile Na in prickly pear cactus cladodes is low (Ben Salem et al. 2002). Tegenge (2002) reported Na values of $0.5 \mathrm{~g} \mathrm{~kg}^{-1} \mathrm{DM}$, higher than what was found in this study, RodríguezGarcía et al. (2007) mentioned that the Na content in the prickly pear cactus is in function of its age. The content of $\mathrm{Cu}, \mathrm{Fe}, \mathrm{Zn}$ and $\mathrm{Mg}$, agrees with those reported by Batista et al. (2003), except for some values of $\mathrm{Zn}$ of 20 to $358 \mathrm{mg} \mathrm{kg}^{-1} \mathrm{DM}$ and Mn 65 to $220 \mathrm{mg} \mathrm{kg}^{-1} \mathrm{DM}$ were higher in the current study.

Gas production and in vitro digestibility

Regarding to the released gas as a product of the fermentation of the components of the prickly pear cactus, in this research the maximum values presented had ranges from 235 to $378 \mathrm{~mL} \mathrm{~g}^{-1} \mathrm{DM}$ at $72 \mathrm{~h}$ of incubation, similar to those reported by Abidi et al. (2009) with $290 \mathrm{~mL} \mathrm{~g}^{-1} \mathrm{DM}$ when a variety of thorny prickly pear cactus was evaluated. The average of gas production during the first eight hours of incubation was $107 \mathrm{ml} \mathrm{g}^{-1} \mathrm{DM}$ in this study, meanwhile Batista et al. (2003) and Abidi et al. (2009) report lower values with 87 and $75 \mathrm{~mL} \mathrm{~g}^{-1}$ DM during the first 8 h of incubation. The average produced gas in $24 \mathrm{~h}$ was $106 \mathrm{~mL} \mathrm{~g}^{-1}$ $\mathrm{DM}$, a higher value than that found by Batista et al. (2003; $\left.72 \mathrm{~mL} \mathrm{~g}^{-1} \mathrm{DM}\right)$, but the values were lower than those found by Abidi et al. (2009) with $134.5 \mathrm{~mL} \mathrm{~g}^{-1}$ DM. Ben Salem et al. (2002) mentioned that the highest gas production occurred during the first $24 \mathrm{~h}$ of incubation without significant increases in the remaining time, which agrees with the data of this study, where $67 \%$ of the total gas production occurs during the first $24 \mathrm{~h}$ of incubation. At $48 \mathrm{~h}$ of incubation the production of gas decreases with only $16 \%$ of the total volume of gas, on average from hour 24 to $50 \mathrm{~h}$ only $60 \mathrm{~mL} \mathrm{~g}^{-1}$ $\mathrm{DM}$ was produced, however, the values were higher than those reported by Batista et al. $\left(2003 ; 35 \mathrm{~mL} \mathrm{~g}^{-1}\right.$ DM), Abidi et al. (2009; $\left.39 \mathrm{~mL} \mathrm{~g}^{-1} \mathrm{DM}\right)$ and Ben Salem et al. (2002; $\left.15.5 \mathrm{~mL} \mathrm{~g}^{-1} \mathrm{DM}\right)$. The degradation rate was lower than that reported by Çürek and Özen (2004), with $0.067 \mathrm{~h}^{-1}$. The average of lag time was $1.45 \mathrm{~h}$, higher than those reported by Batista et al. (2003; $0.63 \mathrm{~h}$ and 2009; $0.13 \mathrm{~h}$ ). The IVDMD fluctuated in ranges from 69 to $82 \%$, values which agree with Çürek and Özen (2004; $64 \%$ ), Tegegne (2002; 69 \%), Araújo et al. (2008; $78 \%$ ), Blakenship et al. (1982; $65 \%)$, and Batista et al. (2009; $70 \%)$. The high degradability of the prickly pear cactus is due to the amount of nonstructural carbohydrates (on average $68 \%$ ) and low lignin content.

\section{Conclusion}

The nutrient content varied among cultivars, low contents of dry matter, high in ashes, moderate in crude protein and fibers were found. During the first $24 \mathrm{~h}$, the cultivars presented more than $50 \%$ of the total gas produced, and in some cases digestibility higer than $80 \%$. It can be concluded that the cladodes of prickly pear cactus from different cultivars can be used in animal feed because of their good rumen fermentation characteristics. 
Acknowledgments This work was a part of PhD thesis of the first author under the supervision of Dr. Luis Alberto Miranda Romero. Authors would to thankful the financial support received form CONACYT and Universidad Autónoma Chapingo.

\section{References}

Abidi S, Ben Salem H, Martín-García AI, Molina-Alcaide E (2009) Ruminal fermentation of spiny (Opuntia amyclae) and spineless (Opuntia ficus indica f. inermis) cactus cladodes and diets including cactus. Anim Feed Sci Technol 149:333-340

Aguilar-Yáñez MI, Hernández-Mendo O, Guerrero-Legarreta I, Ramírez-Bribiesca JE, Aranda-Osorio G, Crosby-Galván MM (2011) Productive response of lambs fed with fresh or dehydrated spineless cactus (Opuntia ficus-indica L.). J Prof Assoc Cactus Dev 13:23-35

Andrade-Montemayor HM, Córdova-Torres AV, García-Gasca T, Kawas JR (2011) Alternative foods for small ruminats in semiarid zones, the case of Mesquite (Prosopis laevigata spp.) and Nopal (Opuntia spp.). Small Rumin Res 98: $83-92$

AOAC (Asociación de Químicos Analíticos Oficiales) (1990) Official methods of analysis, 15th edn. Association of Official Agricultural Chemists, Washington, DC

Araújo FL, Silva FLH, Brito EA, Oliveira Júnior S, Santos ES (2008) Protein enrichment of cactus pear with Saccharomyces cerevisiae for ruminants feeding. Arquivo Brasileiro de Medicina Veterinária e Zootecnia 60:401-407

Barbosa G, Costa JRG, Medeiros AN, Egypto Queiroga RCR, Batista AMV, Medeiros GR, Filho EMB (2012) Use of different urea levels in the feeding of Alpine goats. Revista Brasileira de Zootecnia 41(7):1713-1719

Batista AM, Mustafa AF, McAllister T, Wang Y, Soita H, McKinnon JJ (2003) Effect of variety on chemical composition, in situ nutrient disappearance and in vitro gas production of spineless cacti. J Sci Food Agric 88:440-445

Batista AMV, Ribeironeto AC, Lucena RB, Santos DC, Dubeux JB Jr, Mustafa AF (2009) Chemical composition and ruminal degradability of spineless cactus grown in Northeastern Brazil. Rangel Ecol Manag 62:297-301

Ben Salem H, Nefzaoui A, Ben Salem L (2002) Supplementation of Acacia cyanophylla Lindl. foliage based diets with barley or shrubs from arid areas (Opuntia ficus indica $\mathrm{f}$. inermis and Atriplex nummularia L) on digestibility and growth in sheep. Anim Feed Sci Technol 96:15-30

Blakenship LH, Varner LW, Lynch GW (1982) In vitro digestibility of South Texas range plants using inoculum from four ruminant species. J Range Manag 35:664-666

Cobos MA, Yokoyama MT (1995) Clostridium paraputrificum var ruminantum: colonization and degradation of shrimp carapaces in vitro observed by scanning electron microscopy. In: Wallas RJ, Lahlou-Kassi A (eds). Rumen Ecology Research Planning, Proceedings of a Workshop, Addis Abeba, Ethiopia. International Livestok Research Institute, pp. 151-161

CONAZA (Comisión Nacional de las Zonas Áridas) (1994) Nopal tunero (Opuntia spp.), cultivo alternativo para las zonas áridas y semiáridas de México. Saltillo, Coah, México

Costa RG, Filho EMB, Medeiros AN, Givisiez PEN, Egypto Queiroga RCR, Melo AAS (2009) Effect of increasing levels of cactus pear (Opuntia ficus-indica L. Miller) in the diet of dairy goats and its contribution as a source of water. Small Rumin Res 82:62-65

Çürek M, Özen N (2004) Feed value of cactus and cactus silage. Turk J Vet Anim Sci 28:633-639

De Waal HO, Zeeman DC, Combrinck JW (2006) Wet faeces produced by sheep fed dried spineless cactus pear cladodes in balanced diets. S Afr J Anim Sci 36:10-13

Dubeux C Jr, Santos MVF, Lira MA, Santos DC, Farias I, Lima LE, Ferreira RLC (2006) Productivity of Opuntia ficusindica (L.). Miller under different $\mathrm{N}$ and $\mathrm{P}$ fertilization and plant population in North-East Brazil. J Arid Environ 67:357-372

Felker P, Paterson A, Jenderek MM (2006) Forage potential of Opuntia clones maintained by the USDA National Plant Germplasm System (NPGS) collection. Crop Sci 46:21612168

Fuentes-Rodríguez J (1997) Feeding prickly pear cactus to small ruminants in Northern Mexico. I. Goats. J Prof Assoc Cactus Dev 2:23-25

García E (1988) Modificaciones al sistema de clasificación climática de Koppen (para adaptarla a las condiciones de la República Mexicana). 4th edn. México Distrito Federal

Gebremariam T, Melaku S, Yami A (2006) Effect of different levels of cactus (Opuntia ficus-indica) inclusion on feed intake, digestibility and body weight gain in tef (Eragrostis tef) straw-based feeding of sheep. Anim Feed Sci Technol 131:42-51

Granados D, Castañeda AD (1996) El nopal: historia, fisiología, genética e importancia frutícola. Editorial Trillas, México, $227 \mathrm{pp}$

Kafkafi U, Xu GH (1999) Potassium nutrition for high crop yields. In: Oosterhuis DM, Berkowitz G (eds) Frontiers in potassium nutrition: new perspectives on the effects of potassium on physiology of plants. Georgia, USA, pp. 133-142

Luttge U (2004) Ecophysiology of crassulacean acid metabolism (CAM). Ann Bot 93:629-652

McConn MM, Nakata PA (2004) Oxalate reduces calcium availability in the pads of the prickly pear cactus through formation of calcium oxalate crystals. J Agric Food Chem 52:1371-1374

Menke KH, Steingass H (1988) Estimation of the energetic feed value obtained from chemical analysis and in vitro gas production using rumen fluid. Anim Res Dev 28:7-55

Muciño-Castillo G, Miranda-Romero LA, González-Muciño S, Bárcena-Gama R, Crosby-Galván MMM (2014) Efecto de la inclusión de harina de nopal en dietas en la fermentación in vitro y engorda de corderos. In: Memorias of the XLI Reunión de la Asociación Mexicana para la Producción Animal y Seguridad Alimentaria A. C. y VII Reunión Nacional de Sistemas Agro y Silvopastoriles. Mérida, Yucatán, pp. 340-345

Nobel PS (2002) Ecophysiology of Opuntia ficus-indica. In: Mondragon-Jacobo C, Perez-Gonzalez S (eds) Cactus (Optunia spp.) as forage. FAO Plant Protection and Production Paper 169, Rome, Italy, pp. 13-20 
NRC (National Research Council) (2001) Nutrient requirements of dairy cattle: seventh revised edition. National Academy Press, Washington, DC

Pinos-Rodríguez JM, Velázquez JC, González SS, Aguirre JR, García JC, Álvarez G, Jasso Y (2010) Effects of cladode age on biomass yield and nutritional value of intensively produced spineless cactus for ruminants. S Afr J Anim Sci 40:245-250

Pitt RE, Cross TL, Pell AN, Shofield P, Doane PH (1999) Use of in vitro gas production models in ruminal kinetics. Math Biosci 159:145-163

Rodríguez FH, Jiménez L, Rodríguez Absi JR, Jiménez GG (2009) Cultivo Orgánico del Nopal. Trillas, México

Rodríguez-García ME, Lira C, Hernández-Becerra E, CornejoVillegas MA, Palacios-Fonseca AJ, Rojas-Molina I, Reynoso R, Quintero LC, Real A, Zepeda TA, Muñoz-Torres C (2007) Physicochemical characterizacion of nopal pads (Opuntia ficus indica) and dry vacuum nopal powders as a function of the maturation. Plant Foods Hum Nutr 62:107-112

SIAP (Servicio de Información Agroalimentaria y Pesquera) (2010) www.siap.gob.mx/index.php?option=com_content $\&$ view=article \&id=23\&Itemid=3. Consultada el 17 de mayo de 2013

Silva VL, Costa LS, Bastos MPV, Macedo Facuri LMA, Rego Júnior NO, Silva MV (2011) Caracterização físico-química e bioquímica do farelo de palma forrageira redonda
(Opuntia ficus) utilizado na alimentação de ruminantes. Publicações em Medicina Veterinária e Zootecnia 5(2):1-13

Sniffen CJ, O'Connor JD, Van Soest PJ, Fox DG, Russell JB (1992) A net carbohydrate and protein system for evaluating cattle diets: II. Carbohydrate and protein availability. J Anim Sci 70:3562-3577

Tegegne F (2001) Nutritional value of Opuntia ficus-indica as ruminant feed in Ethiopia. In: Mondragón-Jacobo C, PérezGonzález S (eds) Cactus (Opuntia spp.) as Forage. FAO Plant Production and Protection Paper 169. Food and Agriculture Organization of the United Nations, Rome, pp 91-99

Tegegne F (2002) Fodder potential of Opuntia ficus-indica. Acta Hortic 581:343-346

Tegegne F, Kijora C, Peters KJ (2007) Study on the level of cactus pear (Opuntia ficus-indica) supplementation to sheep and its contribution as source of water. Small Rumin Res 72:157-164

Theodorou MK, Williams BA, Dhanoa MS, McAllan AB, France J (1994) A simple gas production method using a pressure transducer to determine the fermentation kinetics of ruminant feeds. Feed Sci Technol 48:185-197

Van Soest PJ, Robertson JB, Lewis BA (1991) Methods for dietary fiber, neutral detergent fiber, and non-starch polysaccharides in relation to animal nutrition. J Dairy Sci 74:3583-3597 